\title{
The Choice of Laryngeal Reinnervation Versus Medicalization Laryngoplasty in Unilateral Vocal Fold Paralysis
}

\author{
Heejin Kim (iD \\ 일측성 성대 마비의 치료에서 후두 신경재식법과 내측 후두 성형술의 선택
}

Department of Otorhinolaryngology-Head and Neck Surgery, Dongtan Sacred Heart Hospital, Hallym University College of Medicine, Hwaseong, Korea

김희진

한림대학교 의과대학 동탄성심병원 이비인후과학교실

In unilateral vocal fold paralysis (UVFP) patients, we try to improve their symptoms such as hoarseness or aspiration by restoring nerve functions or medialization laryngoplasty (ML), etc. Until now, ML (thyroplasty and/or arytenoid adduction) is considered as gold standard of treatment for UVFP. However, if recurrent laryngeal nerve (RLN) is damaged and use of RLN is feasible during operation, laryngeal reinnervation (LR) would be a good option. Anastomosis with ansa cervicalis to RLN is most common reinnervation method. Delayed LR may be considered in young patients when the RLN denervation period is not long (less than 2 years) for the treatment of surgery-related UVFP. Injection laryngoplasty and laryngeal framework surgery showed great voice outcomes in UVFP. Combination therapy (neuromuscular pedicle innervation with $\mathrm{ML}$ ) also showed good post-operative voice outcomes even in longer periods (over 2 years). In pediatric patients, LR would be considered as a good treatment option because all procedures need to general anesthesia.

Keywords Vocal cord paralysis; Nerve transfer; Medialization laryngoplasty.

\section{서 론}

일측성 성대 마비는 다양한 원인에 의해 발생할 수 있으며, 후두 내시경으로 검진 결 과 성대 마비가 확인되면 경부 전산화단층촬영(computed tomography) 등을 통해 두 개저에서부터 흥곽 내 대동맥 궁까지 마비를 일으키는 병변 여부를 확인하게 된다. 치 료를 결정하기에 앞서 발생한 성대 마비의 회복 가능성을 판단하는 것이 중요하다. 회복 가능성은 마비의 원인과도 관련이 있으며, 성대 마비의 발생 시점 및 후두 근전도 (electromyography) 검사 결과 등이 도움이 될 수 있다. 일반적으로 성대 마비가 회복 될 수 있는 시기는 마비 후 6 12개월 정도로 알려져 있다. ${ }^{1,2)}$ 일측성 성대 마비의 치료 목표는 신경 기능을 회복하거나, 혹은 성대 마비로 인한 증상을 호전시키는 것이며, 전
Received December 12, 2019

Revised January 23, 2020

Accepted February 19, 2020

\section{Corresponding Author}

Heejin Kim, MD

Department of Otorhinolaryngology-

Head and Neck Surgery,

Dongtan Sacred Heart Hospital,

Hallym University College of Medicine,

7 keunjaebong-gil,

Hwaseong 18450, Korea

Tel +82-31-8086-2670

$\mathrm{Fax}+82-31-8086-2681$

E-mail heejin5020@hanmail.net

\section{ORCID iD}

Heejin Kim (D)

https://orcid.org/0000-0001-6157-3636

This is an Open Access article distributed under the terms of the Creative Commons Attribution Non-Commercial License (https://creativecommons.org/ licenses/by-nc/4.0) which permits unrestricted non-commercial use, distribution, and reproduction in any medium, provided the original work is properly cited. 
자의 방법으로는 후두 신경재식법(laryngeal reinnervation, LR), 후자로는 내측화 후두성형술(medialization laryngoplasty, ML) 혹은 음성 치료 등을 고려할 수 있다. 많은 경우, 성대 마비로 인한 흡인 위험을 줄이거나 음성을 호전시키기 위해 성대의 내측화를 시도하게 되며, 일반적으로 성대 주입 성형술(injection laryngoplasty)이나 후두 골격 수술(laryngeal framework surgery) 등을 고려할 수 있다.

한편, 성대 마비를 일으키는 여러 요인 중 수술 등에 의한 의인성 마비가 늘고 있으며, 보고에 따르면 갑상선 절제술 후 영구적인 성대 마비가 발생할 확률은 0.3 3\%에 달하며, 특 히 재수술의 경우 2 30\%까지 위험도가 높아진다고 한다. ${ }^{3}$ 특히 갑상선 절제술의 경우, 종양이 되돌이 후두신경(recurrent laryngeal nerve)을 침습한 경우 종양을 남기지 않기 위 해 신경을 절단할 수 있으며 이로 인해 성대 마비가 발생하게 된다. 수술 중 되돌이 후두신경의 손상이 직접적으로 확인되 는 경우, 수술 중 혹은 수술 후 성대 마비에 대한 치료 방법 으로써 후두 신경재식법과 내측화 후두성형술 등을 선택할 수 있다.

\section{본 론}

\section{후두 신경재식법(Laryngeal reinnervation)}

후두 신경재식법의 목적은 후두 내 근육의 크기 및 긴장도 를 유지함으로써 내전(adduction)과 외전(abduction) 등 상 반된 역할을 하는 근육들 사이에서 균형을 이루도록 하는 것이다. 그렇게 함으로써 성대의 크기 및 유연성을 유지할 수 있으며, 피열 연골이 올바른 위치를 유지할 수 있다. 물론, 후 두 신경재식법을 통해 음성이나 호흡과 관련된 움직임 기능 을 회복하는 것은 기대할 수 없다. 후두 신경재식법의 장점 은 재지배된 근육의 휴지 시 긴장도를 유지함으로써 성대의 위축을 방지할 수 있다는 것과 성대의 탄성도가 변화하지 않 는다는 점이다. 또한 다른 내측화의 문제점인 이물질로 인한 지연성 염증반응이 일어나거나, 연령과 관련된 연골의 석회 화, 근육의 위축과 같은 문제 없이 평생 동안 같은 결과를 유 지할 수 있다는 점이다. 게다가 추가적인 내측화 수술을 동시 에 혹은 추후에 시행할 수 있다는 장점이 있다. 한편, 후두 신경재식법이 효과를 나타내기까지는 보통 6 9개월 정도의 시간이 걸린다고 알려져 있으며, 그러한 이유로 수술 이후 초 기에는 탈신경(denervation)으로 인해 음성이 더 악화될 수 있다. 또한 동조운동(synkinesis)이 문제가 될 수 있는데, 후 두 신경재식법에서 동조운동은 1982년 처음 알려졌으며 되 돌이 후두신경에서 내전과 외전에 관련된 액손(axon)은 무 작위로 위치되어 있으므로, 액손이 끊기게 되면 내전성 액손
이 외전성 근육에 무작위로 재이식되어 동조운동이 발생하 게 된다. ${ }^{4)}$ 동조운동은 2000년에 Crumley ${ }^{5}$ 가 4 개의 유형으 로 구분하였는데, 유형 I은 성대의 움직임이 마비되거나 잘 움직이지 않는 것이지만 음성에는 영향을 주지 않으며, 유형 II의 경우 연축성의 경련과 같은 떨림이 있는 성대로 음성 및 기도의 유지가 어려울 수 있다. 유형 III은 과도하게 내전된 성대로 기도 확보의 어려움이 있고, 유형 IV는 과도하게 외전 된 성대로 흡인과 음성 악화의 문제가 있어 유형 I만이 좋은 경과를 보인다고 알려져 있다.

지금까지 밝혀진 후두 재식법의 방법은 직접 단단 문합(direct end to end anastomosis), 유리 신경 이식(free nerve grafting), 신경근육 줄기 이식(neuromuscular pedicle, NMP), 신 경 이식(nerve implantation), 설하신경을 되돌이 후두 신경에 문합(hypoglossal nerve to recurrent laryngeal nerve anastomosis), 경신경 고리를 되돌이 후두신경에 문합(ansa cervicalis to recurrent laryngeal nerve anastomosis) 등이 있다. 일차적으로 신경 봉합술을 시행하는 경우는 보통 의도치 않 게 신경이 잘리는 등 양쪽 신경의 끝이 확인되는 경우로, 신경 과 신경 사이의 거리가 $5 \mathrm{~mm}$ 미만인 경우 무장력의 문합이 가능하다. 이는 신경의 손상이 발견되었을 때 바로 시행할 수 있으며 추후 더 이상의 다른 수술이 필요하지 않을 수 있 다는 장점이 있다. 만약, 신경과 신경의 끝이 $5 \mathrm{~mm}$ 이상인 경 우 장력이 작용하게 되어 유리 신경 이식술을 사용하는데, 일 반적으로 많이 사용하는 신경은 대이개신경(greater auricular nerve, GAN), 경신경 고리, 가로 목 신경(transverse cervical nerve) 혹은 쇄골상신경(supraclavicular nerve) 등이 다.) 신경근육 줄기 이식(NMP)은 1976년 Tucker'에 의해 소 개되었으며, 견갑설골근(omohyoid muscle)의 앞 측면으로부 터 경신경 고리를 포함한 신경근육 줄기를 들어 갑상피열연골 근의 외측 면에 봉합해주는 방식이다. 그 외 1986년 May와 Beery가 같은 방식으로 견갑설골근에서 신경근육 줄기를 들 어 외측 윤상피열근에 봉합하는 방법을 소개하였다. ${ }^{899}$ 두경 부나 경추 신경 수술을 시행하는 경우 이식에 사용할 만한 되 돌이 후두신경을 찾기 어려운 경우들이 있는데, 이러할 때 경 신경 고리를 직접적으로 갑상피열연골근에 이식하는 방식이 2007 년 Su 등이에 의해 소개되었다. 이는 갑상연골에 작은 창을 만들어 갑상피열연골근을 노출시켜 경신경 고리 줄기를 이식하는 방식으로, 10 명 중 8 명에서 음성의 질이 호전되었으 며, 후두 근전도상 갑상피열연골근의 성공적 이식이 확인되었 다고 보고하였다. 하지만 앞선 방법들은 수술의 결과가 일정 하지 않고 수술법이 어려운 문제를 보여, 현재까지는 경신경 고리를 되돌이 후두신경에 문합하는 방법을 가장 유용하게 사용하고 있다. 이 방법은 1924년 Frazier ${ }^{11)}$ 에 의해 처음 소개 


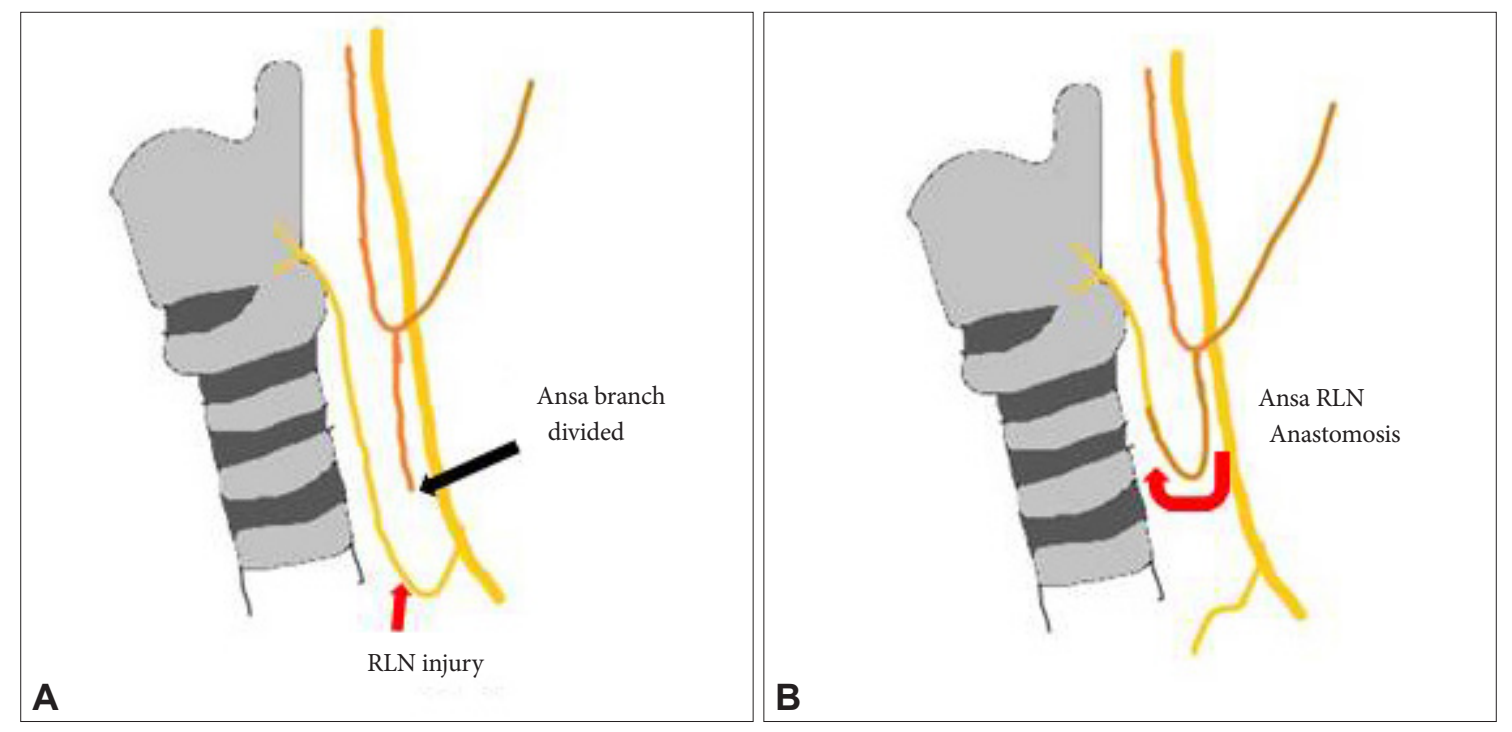

Fig. 1. llustration of ansa cervicalis to recurrent laryngeal nerve anastomosis. A: Illustration of recurrent laryngeal nerve injury and division of a branch of ansa-cervicalis nerve. B: Anastomosis of ansa cervicalis branch and recurrent laryngeal nerve. RLN: recurrent laryngeal nerve.

된 이후, 1986년 Crumley와 Izdebski ${ }^{12}$ 가 그 유용성을 발표 하였다. 수술 방법은 되돌이 후두신경의 끝 부분을 경신경 고 리의 분지 중 하나에 끝과 끝을 문합하는 것이다(Fig. 1). 경 신경 고리를 사용하는 이유는 경신경이 설하신경의 기능에 영 향을 미치지 않아 신경을 절단함에 있어 다른 문제를 일으키 지 않으며, 일부 고유수용성 섬유(proprioceptive fiber)를 제 외하고 견갑설골근, 흥골설골근, 흥골갑상근을 지배하는 순 수 운동 신경이기 때문이다. 또한, 되돌이 후두신경과 $1 \mathrm{~cm}$ 정도 떨어져있을 정도로 가깝고, 직경이 비슷하며 발화 시 자 연적으로 함께 발화하는 성질이 있기 때문이다. ${ }^{13-16)}$ 경신경 고 리에도 여러 분지가 있는데, 후두 신경재식법에 가장 합당한 분지를 찾기 위해 카데바를 이용한 연구가 진행되었고, 결과 적으로 흥골갑상근과 흥골설골근의 공통 분지가 가장 이상적 일 것이라 보고하였다. ${ }^{17)}$ 경신경 고리와 되돌이 후두신경 문 합의 장점은 만약 $1 \sim 2 \%$ 의 확률로 후두 신경재식법이 실패한 다 하여도 추후 성대 주입 성형술을 시행하거나 후두 골격 수 술을 시행할 수 있다는 것이다. ${ }^{18)}$

1966년부터 2009년까지 후두 신경재식법을 연구한 14개 의 논문을 검토한 체계적 문헌고찰에 따르면, 모든 후두 신 경재식법 방법에서 청각학적, 지각적, 근전도, 성문 틈 정도 의 호전을 보였으며, 그 중에서도 경신경 고리와 되돌이 후두 신경 문합 방식이 갑상선 수술 후 $43.5 \%$ 에서 시행된 가장 흔 한 수술이었으며 다른 방법에 비해 성문 틈 정도의 호전을 보였다. ${ }^{14)}$ 후두 신경재식법 수술 1 년 후, 수술 전에 이미 성대 마비가 있었던 환자들과 수술 전 성대의 움직임이 있었던 환 자에게 수술 결과를 비교해 보았을 때 큰 차이를 보이지 않 았고, 모든 음성 지표들이 호전을 보였다. ${ }^{19)}$ 후두 신경재식법
의 장기간 효과에 대해 한 연구에서 3년간 후두 신경재식법 과 성대 주입 성형술의 결과를 비교하였는데, 후두 신경재식 법 그룹에서 수술 36 개월 이후에 성대 주입 성형술 환자보다 더 좋은 음성 결과를 보였다. ${ }^{20}$

한편, 수술 직후가 아닌 지연된 후두 신경재식법(delayed LR)에 대해서 신경 손상 후 2년 이내에는 후두 근육이 지속 적인 재생 가능성을 가지고 있다고 알려져 있다. ${ }^{21)}$ 이러한 수 술을 시행하기 전에는 환자의 나이, 전신 마취가 가능한지, 후두 신경 손상 후 시간이 얼마나 경과하였는지, 이전 어떠 한 범위의 경부 수술을 시행 받았는지에 대해 고려해야 한 다. 또한 점막 병변이나 신경근육 질환의 여부를 확인하여야 하며, 후두 근전도를 통해 후두 근육의 신경생리학적 상태를 확인하고, 전신 마취 하에서 윤상피열관절의 움직임에 대한 평가가 이뤄져야 한다. 한 대규모 연구에서 지연된 후두 신경 재식법의 결과를 분석하였는데, 평균 연령 45.2 세의 237명의 환자를 대상으로 하였고 평균 신경이 손상 받은 기간은 14.4 개월이었으며 2 12년간 추적 관찰을 시행하였다. ${ }^{22)}$ 경신경 고리의 주 분지를 되돌이 후두신경에 문합하는 수술을 시행 하였으며, 모든 스트로보스코피 소견[성문 폐쇄, 성대 연 (vocal fold edge), 성대 위치, 주기성의 대칭 여부, 규칙성]에 서 호전양상을 보였으며, 술 후 음성 지수 또한 확연하게 호 전되었다. 또한 술 후 시행한 후두 근전도 소견에서 후두 근 육에 성공적으로 신경재지배가 일어남을 확인할 수 있었다. 지연된 후두 신경재식법의 효과를 내측화 후두성형술과 비 교한 연구에 따르면 술 후 1년까지 갑상성형술(thyroplasty) 와 비등한 결과를 보였다. ${ }^{23)}$ 특이점은, 후두 신경재식법을 시 행한 그룹에서 52 세 이상의 고령이 젊은 그룹에 비해 결과가 
좋지 않은 반면, 내측화 후두성형술 그룹에서는 52세 이상의 고령에서 확연히 좋은 결과를 보였다는 점이다. 다른 연구에 서도 후두 신경재식법의 결과에 미치는 나이의 영향을 조사 하였고, 349명을 대상으로 30세, 30 44세, 45 59세, 60세 이상으로 그룹을 나누어 각각 경신경 고리와 되돌이 후두신 경 문합술 이후 결과를 비교해보았을 때, 모든 그룹에서 술 후 성공적으로 음성 지표가 호전되었다. ${ }^{24)}$ 하지만 60세 이상 의 그룹에서 다른 그룹에 비해 음성 지표의 호전이 비교적 적은 것을 확인할 수 있었다.

\section{내측화 후두성형술(Medialization laryngoplasty)}

내측화 후두성형술은 성대 주입 성형술, 갑상성형술, 피열 내전술(arytenoid adduction) 등이 있으며, 잘 알려져 있는 것처럼 내측화 후두성형술은 즉각적인 효과를 보이며, 그중 성대 주입 성형술과 갑상성형술은 비교적 간단한 시술로 알 려져 있다. 성대 주입 성형술을 제외하고 다른 후두 골격 수 술은 수술 이후 긴 기간 동안 효과를 보일 것으로 기대된다. 성대 주입 성형술은 시술하는 동안 음성의 변화를 실시간으 로 확인할 수 있으며 기도를 모니터링하며 내전의 정도를 체 크할 수 있다는 장점이 있다. 또한 음성 및 연하 재활의 목적 으로 짧은 시간 내에 외래에서 시술할 수 있으며 이전에 다 른 경부 수술을 받은 여부와 관련 없이 시행할 수 있다는 장 점이 있다. 하지만 일반적으로 반복적인 주입이 필요할 것으 로 생각되며, 기존의 문헌에 의하면 히아루론산(hyalorulonic acid)의 경우 레스티렌(restylene)은 3개월에서 4 6개월, 쥬베덤(juverderm)은 10.6개월 동안 유지되고, 자가 지방 이 식의 경우 1 년 이상, 칼슘 하이트록실아파타이트(calcium hydroxylapatite)는 12 개월 이상, 평균 18.6개월의 유지 기간 을 보인다고 한다. $25-30)$ 그에 반해 후두 골격 수술은 다양한 보형물을 사용할 수 있고 주로 전방부 성문 틈을 줄이기 위 해 사용되며, 비교적 낮은 가격과 술 중 보형물의 크기를 조 정할 수 있고 가역성이 있다는 장점이 있다. 생길 수 있는 합 병증으로는 수술 부위의 감염, 혈종, 후두 부종, 보형물의 이 탈, 기도 폐쇄, 인두피부누공 등으로, 발생률은 술자의 경험 에 따라 2.4 16.7\%까지 보고되고 있다. ${ }^{31)}$ 그동안 영구적 일 측성 성대마비 치료의 표준 치료법으로 갑상성형술이 추천 되었고, 현재까지도 널리 사용되고 있다. 하지만 최근 들어 성대 주입 성형술의 장점이 부각되고, 주입 물질의 발달로 유 지 기간이 길어짐에 따라 성대 주입 성형술과 갑상성형술의 결과가 동등하게 생각되며, 여러 메타분석을 통해 칼슘 하이 드록실아파타이트를 이용한 성대 주입 성형술의 결과가 1년 이상 후에도 갑상성형술에 견줄 수 있음이 확인되었다. ${ }^{32,33)}$

\section{복합 치료(Combination therapy)}

앞서 소개한 후두 신경재식법과 내측화 후두성형술을 함 께 시행하는 시도가 보고되었는데, 이는 후두 신경재식법 이 후 신경 기능이 재생되는 동안 음성 증상을 완화시켜줄 수 있어 상승 작용을 할 것으로 기대된다. 한 연구에서 내측화 후두성형술(갑상성형술)을 시행한 그룹과 내측화 후두성형 술 및 신경근육 줄기 이식 수술을 시행한 그룹을 술 후 3 , 12,24 개월 간격으로 결과를 비교하였다. ${ }^{34)}$ 내측화 후두성형 술 그룹은 시간이 흐름에 따라 점차 음성 지표의 호전 정도 가 줄어드는 반면, 내측화 후두성형술 및 신경근육 줄기 이 식을 함께 시행한 그룹에서는 시간이 흐름에 따라 점차 정상 음성에 가까워지는 정도가 많아짐을 확인할 수 있었다. 또다 른 연구에서는 피열 내전술을 신경근육 줄기 이식과 함께 시 행하였고, 이 결과 또한 수술 3개월 이후 수술 전에 비해 호 전되었던 음성 지표들이 수술 24개월 이후까지 유지되는 것 을 확인할 수 있었다. ${ }^{35)}$

\section{소아의 일측성 성대마비(Pediatric unilateral vocal fold paralysis)}

최근 들어 소아에서도 일측성 성대마비의 빈도가 증가하 고 있다. 여러 원인이 있으나 대부분이 의인성, 특히 동맥관 개존증 결찰(patent ductus arteriosus ligation) 등과 같은 심장 수술과 관련되어 일어날 수 있다. 일반적으로 소아에서 되돌이 후두신경 손상 이후 12 24개월간 증상 호전 여부를 지켜볼 것을 권고하고 있는데, 이는 신경 기능의 회복 확률 이 28 73\%까지 보고되고 있기 때문이다. ${ }^{36-38)}$ 소아의 일측성 성대마비의 치료 방법으로 음성 치료를 비롯하여 수술적 치 료로 성대 주입 성형술, 후두 골격 수술, 후두 신경 재이식 등을 고려할 수 있다. 소아의 경우 특별히 모든 시술을 함에 있어 부분마취가 어렵다는 점이 있어, 성대 주입 성형술과 같 이 반복적인 시술을 시행하는 데 부담이 있으며, 갑상성형술 등과 같은 후두 골격 수술도 전신 마취에서 시행해야 한다는 문제가 있다. 또한 성대 조직이 아직 미성숙하므로 주입된 이 물에 대해 이상 반응을 일으킬 위험이 있다. 실제 몇몇 실험 을 통해 성대 주입 성형술에 흔히 사용되는 히아루론산 등 이 이물 반응을 일으킨 사례들이 보고된 바 있다. ${ }^{39)}$ 또한 후 두가 성장함에 따라 갑상성형술의 보형물 크기가 맞지 않아 변위 되거나 유출될 위험이 있으며, 그로 인해 추가적인 수 술을 시행하게 될 가능성이 있다는 문제가 있어 소아의 일측 성 성대마비의 경우에는 후두 신경재식법을 좋은 치료 방법 중 하나로 생각할 수 있다. 소아에서 치료를 하지 않은 군과 성대 주입 성형술, 경신경 고리와 되돌이 후두신경 문합술을 시행한 그룹 간 치료 성적을 비교한 연구에서, 성대 주입 성 
형술에 비해 후두 신경재식법의 경우 술 후 음성 지표의 호 전 정도가 높게 나타났다. ${ }^{40)}$ 소아 후두 신경재식법 환자의 경 우, 수술을 시행 받는 나이와 음성 호전 정도와는 유의한 관 련을 보이지 않으나, 성대마비가 발생한 시점과 치료까지의 간격과는 유의한 관련성을 보였다. ${ }^{41}$

\section{결 론}

수술 중 되돌이 후두신경의 손상을 확인하였고 신경의 끝 을 확인할 수 있는 상태라면, 수술 중 후두 신경재식법을 곧 바로 시행하는 것을 고려하는 것은 좋은 선택일 수 있겠다. 하지만 지연된 후두 신경재식법을 시행하기 위해서는 치료의 효과에 대해 많은 고려가 필요하며, 특히 젊은 환자이며 수 상 후 기간이 2년 이내인 경우에 선택하는 것이 효과적일 수 있다. 내측화 후두성형술의 경우 성대 주입 성형술 및 후두 골격 수술의 치료 효과는 비등하며, 후두 신경재식법의 효과 가 즉각적으로 나타나지 않으므로 후두 신경재식법과 내측 화 후두성형술을 병합하여 시행하는 치료도 고려할 수 있다. 소아 환자의 경우 성인에서 내측화 후두성형술의 장점이 부 각되지 않으므로, 성대 마비의 치료 선택으로 후두 신경재식 법이 선호될 수 있다.

중심 단어: 성대마비, 후두 신경재식법, 내측 후두 성형술.

\section{Acknowledgments}

None.

\section{Conflicts of Interest}

The author has no financial conflicts of interest.

\section{REFERENCES}

1. Sulica L. The natural history of idiopathic unilateral vocal fold paralysis: evidence and problems. Laryngoscope 2008;118(7):1303-7.

2. Mau T, Pan HM, Childs LF. The natural history of recoverable vocal fold paralysis: implications for kinetics of reinnervation. Laryngoscope 2017;127(11):2585-90.

3. Hayward NJ, Grodski S, Yeung M, Johnson WR, Serpell J. Recurrent laryngeal nerve injury in thyroid surgery: a review. ANZ J Surg 2013;83(1-2):15-21.

4. Flint PW, Downs DH, Coltrera MD. Laryngeal synkinesis following reinnervation in the rat. Neuroanatomic and physiologic study using retrograde fluorescent tracers and electromyography. Ann Otol Rhinol Laryngol 1991;100(10):797-806.

5. Crumley RL. Laryngeal synkinesis revisited. Ann Otol Rhinol Laryngol 2000;109(4):365-71.

6. Sanuki T, Yumoto E, Minoda R, Kodama N. The role of immediate recurrent laryngeal nerve reconstruction for thyroid cancer surgery. J Oncol 2010;2010:846235.

7. Tucker HM. Human laryngeal reinnervation. Laryngoscope 1976;86 (6):769-79.

8. Gacek RR, Malmgren LT, Lyon MJ. Localization of adductor and abductor motor nerve fibers to the larynx. Ann Otol Rhinol Laryngol 1977;86(6 Pt 1):771-6.
9. May M, Beery Q. Muscle-nerve pedicle laryngeal reinnervation. Laryngoscope 1986;96(11):1196-200.

10. Su WF, Hsu YD, Chen HC, Sheng H. Laryngeal reinnervation by ansa cervicalis nerve implantation for unilateral vocal cord paralysis in humans. J Am Coll Surg 2007;204(1):64-72.

11. Frazier $\mathrm{CH}$. The treatment of paralysis of the recurrent laryngeal nerve by nerve anastomosis. Ann Surg 1924;79(2):161-71.

12. Crumley RL, Izdebski K. Voice quality following laryngeal reinnervation by ansa hypoglossi transfer. Laryngoscope 1986;96(6):611-6.

13. Miyauchi A, Matsusaka K, Kihara M, Matsuzuka F, Hirai K, Yokozawa $\mathrm{T}$, et al. The role of ansa-to-recurrent-laryngeal nerve anastomosis in operations for thyroid cancer. Eur J Surg 1998;164(12):927-33.

14. Aynehchi BB, McCoul ED, Sundaram K. Systematic review of laryngeal reinnervation techniques. Otolaryngol Head Neck Surg 2010; 143(6):749-59.

15. Zheng H, Li Z, Zhou S. Electromyographic study of human extrinsic laryngeal muscles. Zhonghua Er Bi Yan Hou Ke Za Zhi 1995;30(2): 108-10.

16. Faaborg-Andersen K, Vennard W. Electromyography of extrinsic laryngeal muscles during phonation of different vowels. Ann Otol Rhinol Laryngol 1964;73:248-54.

17. Prades JM, Gavid M, Dubois MD, Dumollard JM, Timoshenko AT, Peoc'h M. Surgical anatomy of the ansa cervicalis nerve: which branch to use for laryngeal reinnervation in humans? Surg Radiol Anat 2015;37(2):139-45.

18. Isseroff TF, Pitman MJ. Optimal management of acute recurrnet laryngeal nerve injury during thyroidectomy. Curr Otorhinolaryngol Rep 2013;1(3):163-70.

19. Iwaki S, Maeda T, Saito M, Otsuki N, Takahashi M, Wakui E, et al. Role of immediate recurrent laryngeal nerve reconstruction in surgery for thyroid cancers with fixed vocal cords. Head Neck 2017;39 (3):427-31.

20. Lee SW, Park KN. A long-term comparative prospective study between reinnervation and injection laryngoplasty. Laryngoscope 2018; 128(8):1893-7.

21. Donghui C, Shicai C, Wei W, Fei L, Jianjun J, Gang C, et al. Functional modulation of satellite cells in long-term denervated human laryngeal muscle. Laryngoscope 2010;120(2):353-8.

22. Wang W, Chen D, Chen S, Li D, Li M, Xia S, et al. Laryngeal reinnervation using ansa cervicalis for thyroid surgery-related unilateral vocal fold paralysis: a long-term outcome analysis of 237 cases. PLoS One 2011;6(4):e19128.

23. Paniello RC, Edgar JD, Kallogjeri D, Piccirillo JF. Medialization versus reinnervation for unilateral vocal fold paralysis: a multicenter randomized clinical trial. Laryngoscope 2011;121(10):2172-9.

24. Li M, Chen D, Song X, Wang W, Zhu M, Liu F, et al. The effect of patient age on the success of laryngeal reinnervation. Eur Arch Otorhinolaryngol 2014;271(12):3241-7.

25. Halderman AA, Bryson PC, Benninger MS, Chota R. Safety and length of benefit of restylane for office-based injection medialization-a retrospective review of one institution's experience. J Voice 2014;28(5):631-5.

26. Bertroche JT, Radder M, Kallogjeri D, Paniello RC, Bradley JP. Patient-defined duration of benefit from juvederm (hyaluronic acid) used in injection laryngoplasty. Laryngoscope 2019;129(12):2744-7.

27. Pagano R, Morsomme D, Camby S, Lejeune L, Finck C. Long-term results of 18 fat injections in unilateral vocal fold paralysis. J Voice 2017;31(4):505.e1-9.

28. Tucker HM. Direct autogenous fat implantation for augmentation of the vocal folds. J Voice 2001;15(4):565-9.

29. Rosen CA, Gartner-Schmidt J, Casiano R, Anderson TD, Johnson F, Remacle M, et al. Vocal fold augmentation with calcium hydroxylapatite: twelve-month report. Laryngoscope 2009;119(5):1033-41

30. Carroll TL, Rosen CA. Long-term results of calcium hydroxylapatite 
for vocal fold augmentation. Laryngoscope 2011;121(2):313-9.

31. Rosen CA. Complications of phonosurgery: results of a national survey. Laryngoscope 1998;108(11 Pt 1):1697-703.

32. Shen T, Damrose EJ, Morzaria S. A meta-analysis of voice outcome comparing calcium hydroxylapatite injection laryngoplasty to silicone thyroplasty. Otolaryngol Head Neck Surg 2013;148(2):197-208.

33. Siu J, Tam S, Fung K. A comparison of outcomes in interventions for unilateral vocal fold paralysis: a systematic review. Laryngoscope 2016;126(7):1616-24.

34. Tucker HM. Long-term preservation of voice improvement following surgical medialization and reinnervation for unilateral vocal fold paralysis. J Voice 1999;13(2):251-6.

35. Hassan MM, Yumoto E, Sanuki T, Kumai Y, Kodama N, Baraka MA, et al. Arytenoid adduction with nerve-muscle pedicle transfer vs arytenoid adduction with and without type I thyroplasty in paralytic dysphonia. JAMA Otolaryngol Head Neck Surg 2014;140(9): 833-9.

36. King EF, Blumin JH. Vocal cord paralysis in children. Curr Opin
Otolaryngol Head Neck Surg 2009;17(6):483-7.

37. Jabbour J, Martin T, Beste D, Robey T. Pediatric vocal fold immobility: natural history and the need for long-term follow-up. JAMA Otolaryngol Head Neck Surg 2014;140(5):428-33.

38. de Gaudemar I, Roudaire M, François M, Narcy P. Outcome of laryngeal paralysis in neonates: a long term retrospective study of 113 cases. Int J Pediatr Otorhinolaryngol 1996;34(1-2):101-10.

39. Moon IH, Park KN, Kim HK, Lee S. Utility and safety of commercially available injection laryngoplasty materials in a rabbit model. J Voice 2015;29(1):125-8.

40. Zur KB, Carroll LM. Recurrent laryngeal nerve reinnervation in children: acoustic and endoscopic characteristics pre-intervention and post-intervention. A comparison of treatment options. Laryngoscope 2015;125(Suppl 11):1-15.

41. Smith ME, Houtz DR. Outcomes of laryngeal reinnervation for unilateral vocal fold paralysis in children: associations with age and time since injury. Ann Otol Rhinol Laryngol 2016;125(5):433-8. 